\title{
PINA, Manuel António. $O$ coração preparado para o roubo: poemas escolhidos. Seleção e posfácio de Leonardo Gandolfi. São Paulo: Editora 34, 2018.
}

Thiago Bittencourt de Queiroz

Universidade de São Paulo (USP), São Paulo, São Paulo / Brasil

thiagobitq@yahoo.com.br

Recebido em: 30 de maio de 2019.

Aprovado em: 28 de julho de 2019.

A poesia de Manuel António Pina (1943-2012), cuja publicação do primeiro livro data de 1974 e se estendeu até o ano de sua morte, demorou a chegar no Brasil. No entanto, isso não é o fim nem o princípio do mundo, calma é apenas um pouco tarde, para citar o longo e irônico título do primeiro livro de poemas publicado por Pina. Um pouco tarde para a divulgação no Brasil de um poeta que já recebeu o prestigiado prêmio Camões em 2011 e que é, nas palavras de Arnaldo Saraiva, "uma das mais interessantes personalidades da literatura portuguesa" (1993, p 14).

Entretanto, não se trata ainda da poesia completa de Manuel António Pina, mas de uma antologia. Porém, é uma antologia bastante esmerada e que perpassa os onze livros de poesia do autor. Organizado pelo poeta e professor Leonardo Gandolfi, o livro intitulado $O$ coração pronto para o roubo conta com mais de oitenta poemas que vão das publicações de 1974 a 2012. Além da seleção de poemas, o volume ainda traz um posfácio do organizador e trechos de entrevistas. Paratextos esses 
que auxiliam o leitor a compreender a importância do autor no contexto poético português, bem como introduzir certas recorrências temáticas dessa obra.

Primeiramente, ao entrar na poesia de Pina é preciso saber que se trata de um poeta bastante peculiar em termos de afiliações a tendências ou correntes literárias. No posfácio, Gandolfi toma emprestada da pesquisadora Rita Basílio (a primeira autora de uma tese totalmente dedicada ao poeta) a imagem de "forasteiro" para caracterizar o lugar do poeta em relação ao contexto literário português. Não à toa, em seu primeiro livro, temos uma seção intitulada "Billy the Kid de Mota de Pina, Vida Aventurosa e Obra ou Tudo o que Acabou ainda nem Começou", uma brincadeira entre parte de seu nome e o do famoso outlaw americano. Assim, o próprio autor demarca-se como uma voz à margem das tendências poéticas em vigência.

Contudo, essa poesia não surge sem nenhum referencial ou diálogo com a tradição, muito pelo contrário. O poeta considera-se "um ladrão de túmulos" (2018, p. 122) e seu trabalho "uma arte escura de ladrões que roubam ladrões" (2018, p. 123). Desse modo, ler a poesia de Manuel António Pina é entrar em um labirinto intertextual de alusões, citações e referências a inúmeros autores da literatura e filosofia. $\mathrm{O}$ diálogo vai, por exemplo, de Dante a Paul Celan; ou de Camões a um poeta contemporâneo como António Franco Alexandre. Porém, longe de criar um academicismo ou uma erudição desnecessária, as citações e alusões são essenciais para a sua construção poética, pois colocam em evidência não somente a remissão à tradição literária, mas também um embate com ela:

[..]

no meio de palavras minhas e palavras alheias, quem, se eu gritar, me ouvirá entre as legiões dos anjos?

E nem isto me pertence,

a tua ausência e o meu medo;

nem estou na minha ausência,

fui como um vaso e quebrei-me ou qualquer coisa assim.

(2018, p. 95) 
A mesma tradição que alimenta seus poemas também causa angústia em relação ao ofício do poeta. Ele se vê diante da aporia entre o próprio e o alheio, em que não é possível encontrar qualquer pertencimento. Parece-lhe muito própria a sua angústia, a vontade de gritar, mas o verso que o segue vem das Elegias de Duíno, de Rilke. Ou ainda, a indefinição (própria do poeta?) contida na expressão "qualquer coisa assim" no último verso, mas que é antecedida (sempre em itálico) por uma alusão ao início do poema "Apontamento", de Álvaro de Campos. Aliás, a poesia de Fernando Pessoa é uma forte presença na obra do autor. Segundo Gandolfi (2018, p. 148), "entre os poetas surgidos nos anos sessenta, ele [Pina] é o que estabelece uma vizinhança temática e imagética mais próxima com a obra do criador dos heterônimos".

Além dessa tensão entre próprio e alheio, a obra do autor antologiado gira em torno de diversas aporias e ambivalências, como palavra e silêncio; identidade e alteridade; morte e vida; o aparente e o real; tradição e ruptura. Tais problemáticas surgem de uma obsessão temática: a dúvida e indagação constante sobre a linguagem. Tal indagação aparece de modo flagrante no mote "Com que palavras e sem que palavras?" que se repete em diferentes poemas e anima a poética de MAP. A ambivalência entre a possibilidade do dizer e os limites da linguagem surge em versos como ":as palavras não chegam/ a palavra azul não chega" (2018, p. 93). Entretanto, a linguagem é sua única ferramenta para tentar entender o "enigma do mundo"(2018, p. 93). E, desta forma, nas palavras de Paola Poma, pesquisadora brasileira que tem se dedicado ao autor: "mesmo diante da insuficiência da linguagem para dizer o ser e o mundo, pela poesia se pode preencher o silêncio daquilo que não se explica, não se revela, não se diz." (POMA, 2010, p. 229). "O que é feito de nós senão/ as palavras que nos fazem?" (2018, p. 16) indaga-se o poeta em outro poema. Ou partindo do famoso verso de Sá de Miranda: “caem co'a calma as palavras / que sustentam o mundo" (2018, p. 112).

Portanto, adentrar aos poemas dessa importantíssima antologia para o leitor brasileiro é encontrar uma recusa à tentativa, sempre frustrada, de descobrir a essência das coisas, o mistério por trás das palavras, mas colocar em xeque a existência ou importância de tais noções. É um exercício de ceticismo, um princípio da incerteza (como o da física quântica, tão cara ao poeta), em que "Já não é possível dizer mais nada / mas também não é possível ficar calado" (2018, p. 16). Diante disso, que o leitor siga o conselho do poeta: "Aqui estão as palavras, metei o focinho nelas" (2018, p. 27). 


\section{Referências}

PINA, Manuel António. O coração preparado para o roubo: poemas escolhidos. Seleção e posfácio de Leonardo Gandolfi. São Paulo: Editora 34, 2018.

PINA, Manuel António. Todas as palavras: poesia reunida. Lisboa: Assírio \& Alvim, 2012.

POMA, Paola. Deslocamentos na poesia de Manuel António Pina. In: Inimigo Rumor, n. 20. Rio de Janeiro: 7 Letras, 2008. p. 224-232.

SARAIVA, Arnaldo. A poesia de Manuel António Pina: espelho hesitante. JL-Jornal de Letras, Artes e Ideias, Lisboa, n. 556, 2 mar. 1993. 